\title{
Hubungan Karakteristik Santri, Mutu Makanan, dan Daya Terima Konsumsi Santri Di SMA Al Izzah International Islamic Boarding School Kota Batu
}

\section{The Correlation between Characteristics of Students, Food Quality and Food Acceptability among Santri at the Al Izzah International Islamic Boarding School Batu}

\author{
Syahida Ilma Amalia
}

abstrak

Latar Belakang: Penyelenggaraan makanan dapat dikatakan baik jika daya terima konsumennya juga tinggi. Faktor yang dapat mempengaruhi daya terima konsumen adalah karakteristik konsumen dan mutu makanan dari penyelenggara makanan tersebut.

Tujuan: Tujuan dari penelitian ini adalah menganalisis hubungan antara karakteristik santri dan mutu makanan dengan daya terima konsumsi pada penyelenggaraan makanan di SMA Al Izzah IIBS Batu.

Metode: Penelitian ini merupakan penelitian observasional dengan desain penelitian cross sectional. Sampel penelitian sebesar 67 orang, diambil secara acak menggunakan proportionate stratified random sampling. Variabel karakteristik santri dan mutu makanan diobservasi dengan metode wawancara dan penyebaran kuesioner, sedangkan variable daya terima diobservasi dengan metode penimbangan jumlah sisa makanan.

Hasil: Hasil penelitian menunjukkan bahwa konsumen utama pada penyelenggaraan makanan disana mayoritas adalah remaja berusia 16 tahun yang berasal dari Jawa, mutu makanan yang ada di SMA Al Izzah sudah tergolong cukup baik $(T C R=50,25)$, dan daya terima santri juga sudah baik $(n=98,5 \%)$. Kemudian pada variabel karakteristik responden tidak terdapat hubungan dengan daya terima konsumsi yaitu usia responden $(p=0,38)$, tingkat pendidikan $(p=0,48)$, dan asal daerah $(p=0,29)$. Variabel mutu makanan $(p=1,00)$ juga tidak berhubungan dengan daya terima konsumsi pada santri.

Kesimpulan: Mutu makanan pada penyelenggaraan makanan di SMA Al Izzah IIBS Batu terbilang cukup baik dengan daya terima konsumsi santri yang juga baik. Meskipun tidak terdapat hubungan antara keduanya karena daya terima konsumsi tidak hanya dipengaruhi oleh faktor mutu makanannya saja melainkan mutu pelayanan dan sanitasi hygiene dari penjamah makanan disana.

Kata kunci: karakteristik responden, mutu makanan, penyelenggaraan makanan, daya terima konsumsi

\section{ABSTRACT}

Background: The good quality of food service management is reflected when the consumer's food acceptability is also high. Factors that can affect consumer's food acceptability are consumer characteristic and food quality in its food servce management.

Objective: The objective of this study was to analyze the correaltion between consumer characteristic and food quality with consumer's food acceptability at the High School of Al Izzah IIBS Batu.

Method: This was an observational study with cross sectional research design. As the study sample, 67 people were randomly selected using proportionate stratified random sampling technique.

Results: There was no significant correlation between age and food acceptability ( $p$-value $=0.38$ ), no correlation between education level and food acceptability ( $p$-value $=0.48$ ), also no correlation between regional origin and food acceptability $(p$ value $=0.29$ ). There was no correlation between santri characteristics and food acceptability. Also there was no significant correlation between food quality and food acceptability.

Conclusion: Food quality at the High School of Al Izzah IIBS Batu is quite good with the food acceptability is good also. Although there is no correlation between the variables because the food acceptability is not only affected by food quality, but also the quality of service and sanitation hygiene of food handlers there.

Keywords: consumer characteristic, food quality, food service management, food acceptability 


\author{
*Koresponden: \\ Syahida IIma Amalia \\ ilmaamalia17.ia@gmail.com \\ Program Studi IImu Kesehatan Masyarakat, Fakultas Kesehatan Masyarakat, Universitas Airlangga
}

\section{PENDAHULUAN}

Pondok pesantren merupakan lembaga pendidikan unik yang mampu membentuk dan mengembangkan nilai-nilai moral pada diri muridnya hingga menjadi kader sekaligus pencetus pembangkit moral anak bangsa ${ }^{1}$. Para murid pesantren atau disebut sebagai santri yang mengenyam pendidikan di pondok pesantren sama halnya anak didik di sekolah umum yang mampu menjadi sumber daya generasi penerus bangsa dan perlu mendapat perhatian khusus terutama pada kesehatannya dan pertumbuhannya seperti kebutuhan gizi bagi para santri. Jika santri adalah sebutan untuk anak didik di pondok pesantren maka santriwati adalah sebutan khusus untuk anak didik yang berjenis kelamin perempuan yang menempuh pendidikan di pondok pesantren.

Pemantauan status gizi santriwati yang utama seharusnya dilakukan oleh pihak pondok pesantren karena kondisi santriwati yang tinggal jauh dari keluarga sehingga diperlukan tanggung jawab secara penuh atas kesehatan dan pertumbuhan santriwatinya. Hal yang dapat dilakukan untuk melakukan pemantauan status gizi bisa dimulai dari ketika akan mendaftar menjadi santriwati, pihak pondok pesantren sebaiknya melakukan pengukuran antropometri dengan menimbang berat badan dan mengukur tinggi badan, melakukan tensi darah, serta mewawancarai secara singkat masalah terkait gizi yang kemungkinan sudah dimiliki oleh calon santriwati sebelum tinggal di pondok pesantren. Kemudian untuk memantau serta mengevaluasi status gizi santriwati bisa dilakukan hal yang sama namun dilaksanakan setiap 6 bulan sekali.

Ada tiga faktor yang dapat memungkinkan seseorang memiliki status gizi kurang, yaitu adanya penyakit infeksi maupun investasi cacing dalam usus yang dapat menimbulkan kejadian anemia pada remaja putri, adanya penyakit degeneratif seperti jantung koroner dapat memengaruhi status gizi pada remaja, selain itu asupan atau pola konsumsi yang kurang baik juga dapat memengaruhi status gizi pada remaja. Kurang baiknya pola konsumsi pada remaja ini tidak hanya menimbulkan status gizi kurang saja melainkan juga bisa menyebabkan status gizi lebih bahkan obesitas ${ }^{2}$.

Kebiasaan melewati jam makan karena ingin mempunyai bentuk tubuh yang proporsional sehingga dapat menyebabkan badan berstatus gizi kurang. Selain itu, ada dua pola makan abnormal yang bisa menjadi penyebab status gizi lebih bahkan obesitas, yaitu makan dalam jumlah sangat banyak (binge) dan makan di malam hari. Seseorang yang mempunyai dua pola makan ini biasanya dipicu oleh stress dan kekecewaan ${ }^{2}$.

Pada binge karena asupan yang dimasukkan ke dalam tubuh sangat banyak sehingga kalori yang di konsumsi pun juga sangat banyak. Sedangkan pada kejadian sindroma makan pada malam hari yaitu berkurangnya nafsu makan di pagi hari namun makan yang berlebihan, diikuti agitasi dan insomnia di malam harinya ${ }^{2}$. Oleh karena itu, pola konsumsi pada remaja perlu diperhatikan dengan baik sebab remaja sering mengikuti tren yang sedang berlangsung disekitarnya.

Pola konsumsi remaja dapat dipengaruhi oleh gaya hidup, ada juga faktor pemungkin yang dapat memicu kurang baiknya pola konsumsi pada remaja, yaitu kualitas makanan yang ada disekitarnya. Tidak jarang ditemukan, kualitas makanan khususnya di pondok pesantren, termasuk dalam kategori yang kurang baik terutama dalam nilai gizi makanan. Berdasarkan hasil penelitian yang dilakukan di Pondok Pesantren Hubulo Gorontalo, jika dibandingkan dengan Angka Kecukupan Gizi (AKG) 2012 pada santriwati usia 13-15 tahun kebutuhan energinya masih terbilang cukup baik, namun lemak masih $52 \%$ saja yang terpenuhi sehingga banyak santriwati yang mengalami status gizi kurus $^{3}$. Hal tersebut menunjukkan bahwa pola konsumsi santri dipicu oleh mutu makanan yang ada di pondok pesantren.

Pola konsumsi santri juga dapat dipengaruhi oleh kepuasan terhadap pelayanan makan di pondok pesantren. Pada penyelenggaraan makanan di pondok pesantren Al Izzah IIBS Batu terdapat permasalahan yang seringnya diabaikan pihak pengelola seperti sisa lauk nabati (tahu dan tempe) saat makan pagi disajikan ulang untuk makan siang bahkan makan malam tanpa dihangatkan terlebih dahulu, terkadang ditemukan ulat pada olahan sayuran hijau, serta kurang tanggapnya pihak pengelola terhadap keluhan santri atas menu makanan. Beberapa permasalahan ini dapat mempengaruhi pola konsumsi santri. Kepuasan santri yang tinggi terhadap pelayanan makanan akan meningkatkan pola konsumsi sehingga sisa makanan santri akan sedikit. Kepuasan santri terhadap makanan secara signifikan bergantung pada kualitas makanan, variasi menu, sikap penyaji makanan, pelayanan makanan, ketepatan waktu pemberian makan, serta keandalan dalam pelayanan makanan ${ }^{4}$.

Begitu pula sebaliknya, jika kualitas makanan kurang baik maka pola konsumsi santri menurun sehingga menyebabkan ketidakpuasan santri terhadap penyelenggaraan makanan di pondok pesantren. Hal tersebut jika dibiarkan berlangsung akan mempengaruhi status kesehatan santri yang akan menurun, sehingga pada akhirnya prestasi akan menurun dan kualitas santri sebagai sumber daya potensial juga akan menurun. Oleh karena itu, peneliti ingin menganalisis hubungan mutu penyelenggaraan makanan dan kualitas makanan dengan tingkat kepuasan santri di pondok pesantren.

\section{METODE PENELITIAN}

Jenis peneilitian ini merupakan penelitian observasional dengan rancang bangun atau desain 
penelitian cross sectional, karena variabel independen dan variabel dependen diambil pada waktu yang bersamaan. Karakteristik santri, dan mutu makanan pada penyelenggaraan makanan di pondok pesantren merupakan variabel independen sedangkan daya terima konsumsi santri merupakan variabel dependen.

Populasi pada penelitian ini adalah semua santri yang bertempat tinggal di asrama selama 24 jam yang bertingkat pendidikan SMA. Namun pada saat pengambilan data santri kelas 12 telah melaksanakan wisuda dan tidak menetap di asrama sehingga populasi yang digunakan hingga akhir penelitian adalah santri kelas 10 dan kelas 11 . Populasi yang dihitung sebanyak 198 santri.

Sampel pada penelitian ini adalah santri SMA yang telah menetap di pondok pesantren minimal 6 bulan. Teknik pengambilan sampel pada penelitian ini adalah menggunakan Proportionate Stratified Random Sampling yang biasa digunakan pada populasi yang mempunyai susunan bertingkat atau berlapis-lapis. Teknik ini digunakan bila populasi mempunyai anggota/unsur yang tidak homogen dan berstrata secara proporsional $^{5}$. Santri yang akan dijadikan sampel yaitu yang telah dipilih secara acak berdasarkan tingkat pendidikan (kelas). Besarnya sampel pada penelitian sebanyak 66 santri yang ditentukan dengan rumus Slovin.

Penelitian dilakukan di penyelenggaraan makanan di Pondok Pesantren SMA Al Izzah International Islamic Boarding School yang bertempat di Jalan Indragiri Gang Pangkur No. 87 Sumberejo, Kecamatan Batu, Kota Batu, sedangkan waktu penelitian dilakukan pada bulan September 2018 hingga Juli 2019 dan pengambilan data dilaksanakan pada tanggal 19 Juni 2019.

Pemilihan lokasi ini ditentukan berdasarkan penelitian terdahulu yang mengenai higiene sanitasi pada penyelenggaraan makanan dan hubungannya terhadap tingkat pengetahuan dan sikap penjamah makanan di SMA Al Izzah. Berdasarkan penelitian tersebut dinyatakan bahwa penyelenggaraan makanan disana belum memenuhi uji kelaikan fisik menurut Permenkes RI No. 1096/MENKES/PER/VI/2011.

Pengambilan data tentang penyelenggaraan makanan di SMA Al Izzah IIBS Batu melalui wawancara dan disajikan secara deskriptif, data mutu makanan diperoleh melalui penyebaran kuesioner uji hedonik yang diberi skor (1=tidak mengonsumsi, $2=$ sangat tidak suka, $3=$ tidak suka, $4=$ suka, $5=$ sangat suka) pada setiap indikator (rasa, tekstur, warna, dan aroma) lalu nilai TCR (Tingkat Capaian Responden) terhadap mutu makanan dikategorikan sebagai berikut sangat baik (80-100\%), baik (60-79\%), cukup (40-59\%), kurang (<39\%). Data daya terima konsumsi diperoleh dari sisa makanan responden yang melalui proses penimbangan berat porsi menu makanan sebelum dan sesudah dimakan oleh responden dengan menggunakan timbangan dan pencatatan. Penimbangan sisa makanan dilakukan dalam sehari pada menu makan pagi (nasi telur dewata dan tempe goreng), makan siang (nasi, ayam saos balado, sayur asam bening, tahu tempe goreng, dan buah melon), serta makan malam (nasi, tempe tahu rempah, dan oseng kacang panjang). Data mengenai uji hubungan dilakukan dengan uji statistik chi square dengan tingkat kepercayaan $90 \%(\alpha=0,10)$ kemudian disajikan dalam bentuk tabel dan dianalisis secara deskriptif. Pada data hubungan antar variabel akan dilakukan pemampatan kategorisasi pada setiap variabel.

\section{HASIL DAN PEMBAHASAN}

\section{Gambaran Umum Penyelenggaraan Makanan di SMA Al} Izzah IIBS Batu

Lembaga Pendidikan Muslimah Indonesia (LPMI)

Al Izzah berdiri pada tanggal 17 Juli 2006 yang berlokasi di Jalan Indragiri Gang Pangkur No. 87, Sumberejo, Kota Batu. Pada awal tahun 2006 merupakan kali pertamanya Pondok pesantren Al Izzah menyelenggarakan program pendidikan menengah pertama (SMP) kemudian dilanjutkan pada tahun 2011 memulai program pendidikan menengah atas (SMA). Pondok pesantren Al Izzah merupakan sekolah berasrama yang berstandar internasional dan terakreditasi A. Pondok pesantren program SMP-SMA Al Izzah ini mengamalkan ilmu pengetahuan dan teknologi berdasarkan nilai-nilai islami.

Pondok pesantren memiliki dapur sebagai salah satu tempat perolehan makanan bagi santri. Dapur seluas $\pm 200 \mathrm{~m}^{2}$ itu setiap harinya memasak \pm 800 porsi untuk setiap jam makannya. Pada dapurnya terbagi menjadi lima ruangan yang terdiri dari ruang persiapan dan pengolahan makanan, ruang penyimpanan bahan makanan kering, ruang pencucian alat-alat dan bahan makanan, toilet, serta ruang penyajian. Sedangkan ruang makan yang dimiliki oleh pondok pesantren ini berjumlah dua dan bersebelahan langsung oleh dapurnya.

Penyelenggaraan makanan adalah pengadaan makanan yang diberikan kepada suatu kelompok yang berada diluar lingkungan keluarga sebagai pemenuh kebutuhan manusia sesuai dengan kebutuhan gizi yang dibutuhkan tubuh. Penyelenggaraan makanan kelompok dapat dibedakan menurut waktu, sifat, dan tempat sebagai berikut ${ }^{6}$ :

Terdapat tiga pengklasifikasian penyelenggaraan makanan jika berdasarkan waktunya, yaitu penyelenggaraan makanan tetap untuk jangka waktu yang tidak ditentukan, hanya satu kali saja yang berupa makanan lengkap atau hanya makanan ringan (snack food), serta dalam keadaan darurat ${ }^{6}$. Berdasarkan hasil observasi dan wawancara dengan pihak pengelola bahwa penyelenggara makanan di Al Izzah IIBS Batu, berupa penyelenggaraan makanan tetap untuk jangka waktu yang tidak ditentukan dan hanya mengolah makanan lengkap saja, karena makanan ringan atau snack telah disediakan sendiri oleh kantin sekolah. Penyelenggaraan makanan termasuk dalam klasifikasi tersebut karena berada di dalam pondok pesantren sehingga harus melayani dan menyediakan makanan 
lengkap dan bernutrisi bagi para santri selama tinggal di pondok pesantren tersebut.

Terdapat dua pengklasifikasian penyelenggaraan makanan jika berdasarkan sifatnya, yaitu penyelenggaraan makanan komersial dan non komersial ${ }^{6}$. Berdasarkan hasil observasi dan wawancara dengan pihak pengelola bahwa penyelenggara makanan di Al Izzah IIBS Batu berupa penyelenggara makanan non komersil karena tidak menarik keuntungan untuk setiap porsi makanannya pada santri tetapi biaya makan telah diikutsertakan dalam SPP sekolah tiap bulannya. Hal ini bertujuan agar tidak memberatkan para santri jika ingin mengonsumsi makanan yang lengkap dan bernutrisi sehingga dapat meningkatkan produktivitas santri dalam menjalan berbagai kegiatan di pondok pesantren.

Terdapat tiga pengklasifikasian penyelenggaraan makanan berdasarkan tempat memasak dan menyajikan makanan, yaitu jasa boga yang tempat memasak makanan berbeda dengan tempat menghidangkan makanan serta makanan institusi yang berupa antara tempat memasak dengan menghidangkannya berada pada satu tempat yang sama ${ }^{6}$. Sedangkan definisi lain dari penyelenggaraan makanan institusi adalah penyelenggaraan makanan yang dilakukan dalam jumlah besar atau massal ${ }^{7}$. Batasan mengenai jumlah yang diselenggarakan di setiap negara beraneka macam, yang digunakan di Indonesia adalah bila jumlah porsi yang diselenggarakan adalah 150 porsi sehari.

Berdasarkan hasil observasi dan wawancara dengan pengelola, bahwa penyelenggara makanan di Al Izzah IIBS Batu merupakan penyelenggaraan makanan institusi. Hal ini karena pada penyelenggaraan makanan disana terdapat tempat untuk memasak makanan dan menghidangkan makanan dalam bangunan yang sama dan porsi makanan yang diproduksi dalam sekali pengolahan dapat mencapai 800 porsi, sehingga dalam sehari dapat memproduksi sekitar 2400 porsi makanan.

Alur penyelenggaraan makanan dimulai dari penerimaan bahan makanan mentah sampai pemasakan dilakukan di ruang pengolahan. Ruang pencucian bahan makanan disatukan dengan pencucian alat-alat pengolahan makanan di ruangan tersebut yang juga terdapat rak-rak penyimpanan alat-alat bersih. Sebelah ruang pencucian terdapat toilet yang khusus digunakan oleh para penjamah makanan. Sedangkan ruang penyimpanan bahan makanan kering yang hanya diperuntukan menyimpan bahan makanan kering seperti beras, bumbu-bumbu, kerupuk, dan teh kantong berada disebelah ruang penyajian.

Sistem penyelenggaraan makanan menggunakan sistem swakelola yaitu penyelenggara makanan bertanggung jawab secara penuh terhadap pelaksanaan seluruh kegiatan dengan tenaga, dana, metode, sarana dan prasarananya. Kegiatan penyelenggaraan makanan di pondok pesantren ini terdiri dari pengolahan makanan untuk santri dan pengasuh selama $3 x$ sehari serta untuk guru dan karyawan hanya pada saat jam istirahat atau makan siang. Kegiatan penyelengaraan makanan dimulai dari perencanaan menu, pengadaan bahan makanan, penerimaan, penyimpanan, persiapan dan pengolahan bahan makanan hingga penyajian makanan.

\section{a. Perencanaan menu}

Perencanaan menu merupakan kegiatan menyusun menu dengan memadukan variasi hidangan agar serasi dan memenuhi kecukupan gizi konsumennya. Penyelenggaraan makanan Pondok Pesantren Al Izzah menggunakan siklus menu bulanan atau 30 hari sekali. Siklus menu dibuat oleh koki dan terkadang penjamah makanan di dapur kemudian didiskusikan dengan pengelola untuk persetujuan. Salah satu hal yang perlu dipertimbangkan dalam membuat perencanaan menu adalah harus memperhatikan kecukupan gizi konsumennya. Pada penyelenggara makanan di Al Izzah IIBS Batu, menu dalam sehari harus mencakup karbohidrat, protein, lemak, dan serat. Maka dari itu menu sarapan pagi biasanya hanya menu sederhana semisal soto, lalu saat makan siang disediakan menu komplit menggunakan sayur dan buah, sedangkan menu makan malam disajikan yang sedikit berat seperti nasi goreng.

Proses perencanaan menu tidak ada intervensi dari lembaga karena tidak ada larangan khusus terhadap suatu menu. Namun terkadang terkendala dengan keadaan geografis yang berada di dataran tinggi sehingga persediaan ikan laut jarang sekali di pasar, maka dari itu seringkali diganti dengan lauk fillet atau lauk daging ayam.

\section{b. Penganggaran belanja}

Penganggaran belanja merupakan suatu kegiatan perencanaan yang dilakukan dengan istilah moneter agar manajemen penyelenggaraan makanan dapat berputar tanpa adanya hambatan. Biaya makan yang dianggarkan oleh penyelenggaraan makanan ini maksimal Rp10.000 perorang untuk sekali makan. Penganggaran belanja biasanya dilakukan setiap seminggu sekali, berbeda dengan perencanaan menu yang dilakukan setiap sebulan sekali. Prosesnya yaitu ketika awal minggu diberikan budget sekian lalu dilakukan penghitungan setiap harinya kemudian pada akhir minggu dievaluasi dengan melakukan pengecekan terhadap nota-nota dan buku anggaran belanja.

\section{c. Pembelian bahan makanan}

Pembelian bahan makanan merupakan proses pengadaan produk pada waktu yang tepat dengan jumlah, kualitas dan harga yang tepat. Pada penyelenggaraan makanan di Al Izzah IIBS Batu ini menerapkan sistem group and corporate purchasing yaitu dengan cara pengelola telah mempunyai beberapa 
daftar supplier bahan makanan pokok, sehingga ketika akan melakukan pembelian tidak perlu mendatangi tempatnya langsung. Pengelola akan mengorder bahan makanan melalui telepon ke supplier kemudian bahanbahan yang dipesan akan dikirimkan setiap pagi pukul 05.00 WIB. Kegiatan pembelian bahan ini menggunakan spesifikasi bahan seperti penyelenggara makanan tidak akan menerima bahan yang harus disimpan di freezer tetapi harus bahan yang fresh, beras yang diterima harus beras selepan, beberapa sayur yang dipesan pada hari itu juga harus segar tidak boleh terlalu tua, dan sebagainya. Frekuensi pembelian bahan makanan basah seperti daging sapi, daging ayam, ikan laut, sayur dan buah dilakukan setiap hari sekali pada pagi hari, untuk pembelian bahan makanan seperti beras dilakukan setiap 10 hari sekali, sedangkan pembelian bahan makanan kering dilakukan kondisional ketika telah habis akan beli ke pasar oleh beberapa penjamah makanan yang sedang bertugas pada hari tersebut.

\section{d. Penerimaan bahan makanan}

Penerimaan bahan makanan merupakan kegiatan pemeriksaan, pencatatan, meneliti dan memutuskan serta melaporkan mengenai macam dan jumlah bahan makanan sesuai dengan pesanan dan spesifikasi yang telah ditetapkan. Ketika bahan makanan telah dikirim oleh supplier maka akan diterima oleh penjamah makanan yang sedang bertugas pada hari tersebut. Proses penerimaan yang dilakukan tidak sembarangan namun juga dilakukan pengecekan terhadap kesesuaian antara nota, jumlah bahan yang datang, serta kondisi fisik bahan yang harus sesuai dengan spesifikasi yang telah diberikan. Kegiatan penerimaan dan pengecekan dilakukan oleh orang yang sama karena keterbatasan tenaga kerja.

\section{e. Penyimpanan bahan makanan}

Penyimpanan bahan makanan merupakan tata cara menata, menyimpan, memelihara jumlah, kualitas, dan keamanan bahan makanan kering dan segar. Pada penyelenggaraan makanan di Al Izzah IIBS Batu terdapat satu ruangan khusus untuk menyimpan bahan makanan kering yang terdiri dari rak gantung untuk menyimpan bumbu dapur, namun untuk beras tidak menggunakan palette maupun rak karena beras yang tersedia mencapai sekian ton beratnya sehingga hanya diletakkan pada lantai ruangan dan ditumpuk rapi. Sedangkan pada bahan makanan basah hanya disediakan satu kulkas saja karena hanya akan dipakai penyimpanan sementara menu yang akan dimasak pada hari tersebut. Tidak ada teknis khusus dalam proses penyimpanan karena tidak memerlukan waktu yang lama untuk bahan makanan yang tersedia akan habis.

\section{f. Pengolahan bahan makanan}

Pengolahan bahan makanan mulai dari persiapan bahan, pembersihan, pengupasan, pembuangan bagian makanan yang tidak bisa digunakan, memotong, dan pemberian bentuk dengan perawatan serta perlakuan bahan tertentu terhadap bahan makanan sebelum memasak dan menambahkan bumbu. Apabila proses ini dilakukan secara tepat dapat menjadi faktor penting yang akan mempersingkat waktu dalam proses memasak.

Pada proses persiapan bahan biasanya dilakukan oleh koki yang bertugas pada hari tersebut. Pelaksanaan persiapan bahan makanan untuk menu pagi dilakukan pukul 04.00 WIB lalu ketika jam makan pagi telah habis, penjamah makanan yang bertugas sudah harus segera menyiapkan bahan yang akan diolah untuk makan siang, lalu untuk makan malam dilakukan persiapan bahannya pada pukul 14.00 WIB. Terdapat pembagian waktu antara persiapan bahan makanan kering dan basah, penjamah makanan akan melakukan proses pada bahan yang kering terlebih dahulu kemudian yang basah namun untuk sayur akan dilakukan persiapan jika telah mendekati jam makan siang.

Proses pemasakan di penyelengara makanan Al Izzah IIBS Batu dilakukan oleh semua penjamah makanan yang bertugas pada shift kerjanya yaitu 5 orang pada saat makan pagi dan siang, 4 orang pada saat makan malam. Teknik memasak yang diterapkan juga seperti pada umumnya misalnya boiling untuk merebus sayur, simmering untuk membuat soto kaldu dan rawon, stewing untuk kuah sayur yang bersantan, deep frying untuk tahu tempe dan lauk lainnya, serta sauté untuk menumis sayuran. Tidak ada teknik khusus karena keterbatasan peralatan, waktu, dan tenaga.

\section{g. Pendistribusian dan penyajian makanan}

Pendistribusian dan penyajian makanan merupakan tugas terakhir dari petugas penyelenggaraan makanan. Teknik distribusi yang diterapkan oleh penyelenggaraan makanan Al Izzah IIBS Batu adalah campuran dari desentralilasi dan sentralisasi. Santri akan menantri didepan pantry untuk mengambil lauk yang disediakan oleh penjamah makanan, lalu untuk nasi, sayur, buah, dan kerupuk santri dibebaskan memorsi sendiri yang telah disediakan di atas meja. Pemilihan teknik seperti ini digunakan dengan alasan waktu yang ada sangat terbatas, sisa makanan dapat diminimalisir, lalu tenaga yang juga terbatas.

Alat-alat yang digunakan untuk mendistribusikan makanan adalah piring, sendok, garpu, nampan nasi, centong nasi, mangkok sayur, dan centong sayur. Sedangkan makanan yang didalam pantry (lauknya), penjamah makanan akan menggunakan sarung tangan dulu kemudian membagikan lauk ke tiap anak dengan alat capitan makanan. Penyajian akan dilakukan setiap jam makan berlangsung yaitu makan pagi mulai pukul $05.30-06.30$ WIB, makan siang pukul 
11.30 - 13.00 WIB, dan makan malam pukul 17.30 19.00 WIB.

\section{h. Pencatatan dan pelaporan}

Pencatatan dan pelaporan merupakan kegiatan atau proses pendokumentasian suatu aktivitas dalam bentuk tulisan dengan tujuan agar kegiatan dapat dipantau secara terus-menerus meskipun dari jarak jauh. Namun sayangnya, pada penyelenggaraan makanan di Al Izzah IIBS Batu, tidak terdapat pencatatan dan pelaporan pada setiap proses kegiatan manajemen. Pihak pengelola mempercayakan sepenuhnya pada penjamah makanan karena telah lama bekerja disana, sehingga jika terjadi kesalahan pada prosesnya maka akan dijadikan bahan evaluasi pada rapat direksi yang diadakan setiap hari Senin pagi.

\section{i. Pengelolaan limbah}

Pengelolaan limbah harus dilakukan oleh suatu penyelenggara makanan agar tidak mencemari lingkungan sekitar. Pada pondok pesantren ini, limbah dibedakan menjadi dua yaitu limbah padat dan cair. Limbah cair yang dihasilkan oleh penyelenggara makanan langsung dibuang melalui saluran limbah yang telah terkonstruksi dengan baik. Sedangkan limbah padat sisa makanan dikirim ke peternakan mentok yang dimiliki oleh ART disana dan diolah menjadi pupuk. Frekuensi pembuangan limbah padat dilakukan setiap selesai jam makan. Pihak pengelola menyebutkan bahwa di penyelenggaraan makanan SMA Al Izzah IIBS Batu tidak memproduksi limbah B3 (Bahan Berbahaya dan Beracun).

\section{Karakteristik Santri}

Karakteristik santri SMA Al Izzah IIBS Batu meliputi usia, tingkat pendidikan, dan asal daerah. Karakteristik santri disajikan pada tabel 1 yang menunjukkan bahwa keseluruhan santri termasuk dalam kategori remaja menurut WHO yaitu dalam rentang usia $10-21$ tahun. Usia santri dalam penelitian ini termasuk dalam rentang usia remaja yaitu 15 - 18 tahun. Berdasarkan hasil penelitian diketahui bahwa sebagian besar dari santri SMA Al Izzah IIBS Batu yang menjadi responden sebesar $47,8 \%$ berusia 16 tahun. Hal tersebut berarti usia santri termasuk dalam usia remaja tengah sehingga diharapkan santri sudah mencapai transisi perkembangan yang lebih mendekati masa dewasa dan mampu untuk mencapai tingkah laku sosial tertentu yang bertanggung jawab di tengah-tengah masyarakatnya. Menurut Departemen Kesehatan Jakarta I tahun 2010, usia remaja digolongkan menjadi masa remaja awal (10 - 13 tahun), masa remaja tengah (14 16 tahun) dan masa remaja akhir (17 - 19 tahun). Semua santri termasuk dalam kategori remaja tengah dan remaja akhir, yang mana usia remaja memerlukan zat gizi yang lebih tinggi ${ }^{8}$, perubahan gaya hidup, dan kebiasan makan remaja mempengaruhi baik asupan maupun kebutuhan gizinya.
Tingkat pendidikan yang digunakan dalam penelitian ini hanya santri kelas 10 dan kelas 11 sebab pada proses pengambilan data, santri kelas 12 telah melaksanakan wisuda sehingga tidak menetap di pondok pesantren. Oleh karena teknik pengambilan sampel yang dipilih oleh peneliti menggunakan Proportional Stratified Random Sampling maka mayoritas respondennya ialah santri kelas 10 (yaitu 53,7\%) sebab berjumlah lebih banyak daripada santri kelas 11 . Pendidikan merupakan suatu proses atau kegiatan untuk mengembangkan kepribadian dan kemampuan individu dan bertujuan untuk bertahan hidup termasuk dalam memenuhi kebutuhan pangannya?

Tabel 1. Distribusi Karakteristik Santri SMA Al Izzah IIBS Batu

\begin{tabular}{cccc}
\hline \multirow{2}{*}{ Karakteristik Santri } & \multicolumn{2}{c}{ Jumlah (n=67) } \\
\cline { 3 - 4 } Usia: & $\mathbf{n}$ & \% \\
$-\quad 15$ tahun & 9 & 13,4 \\
$-\quad 16$ tahun & 32 & 47,8 \\
$-\quad 17$ tahun & 23 & 34,3 \\
$-\quad 18$ tahun & 3 & 4,5 \\
\hline Tingkat Pendidikan: & & \\
$-\quad$ Kelas 10 & 36 & 53,7 \\
$-\quad$ Kelas 11 & 31 & 46,3 \\
\hline Asal Daerah: & & \\
$-\quad$ Jawa & 47 & 70,1 \\
- Luar Jawa & 17 & 4,5 \\
- & Madura & 3 & 25,4 \\
\hline
\end{tabular}

Pada penelitian ini, asal daerah dikategorikan menjadi 3, yaitu Jawa, Luar Jawa, dan Madura. Pada Tabel 1 menunjukkan bahwa sebagian besar santri berasal dari Jawa, yaitu sebesar $70,1 \%$. Hal ini dikarenakan pondok pesantren Al Izzah IIBS Batu berada di wilayah pulau Jawa khususnya Jawa Timur sehingga banyak santri yang berasal dari daerah tersebut. Responden pada penelitian ini berasal dari beragam daerah yang juga memiliki beragam selera terhadap atribut tertentu yang berhubungan dengan mutu makanan yaitu selera santri terhadap menu yang disajikan tentu berbeda menurut penilaian santri dengan asal daerah yang berbeda. Menurut penelitian yang dilakukan pada salah satu kantin di IPB dengan subjek adalah mahasiswa IPB dan presentase terbesar berasal dari Pulau Jawa ${ }^{10}$

\section{Mutu Makanan pada Penyelenggaraan Makanan}

Mutu makanan suatu penyelenggara makanan dapat dilihat dari tingkat kesukaan seseorang melalui uji hedonik. Uji hedonik dinilai dalam berbagai tingkatan mulai dari sangat suka sampai sangat tidak suka. Penilaian tingkat kesukaan beberapa aspek yang mempengaruhi daya terima terdiri dari penilaian rasa, warna, tekstur, serta aroma terhadap hidangan yang disajikan dalam sehari yang berupa makanan pokok, lauk hewani, lauk nabati, sayuran, dan buah. Tingkat kesukaan subjek terhadap makanan pokok disajikan pada tabel 2. 
Tabel 2. Tingkat Kesukaan Santri berdasarkan Karakteristik Makanan pada Penyelenggaraan Makanan

\begin{tabular}{|c|c|c|c|c|c|c|c|c|c|c|c|c|c|}
\hline \multirow{2}{*}{ Karakteristik } & \multicolumn{2}{|c|}{$\begin{array}{c}\text { Tidak } \\
\text { Mengonsumsi } \\
\end{array}$} & \multicolumn{2}{|c|}{$\begin{array}{l}\text { Sangat Tidak } \\
\text { Suka } \\
\end{array}$} & \multicolumn{2}{|c|}{ Tidak Suka } & \multicolumn{2}{|c|}{ Suka } & \multicolumn{2}{|c|}{ Sangat Suka } & \multirow{2}{*}{ Skor } & \multirow{2}{*}{$\begin{array}{c}\text { Skor } \\
\text { Rata- } \\
\text { Rata }\end{array}$} & \multirow{2}{*}{ TCR } \\
\hline & $\mathrm{n}$ & $\%$ & $n$ & $\%$ & $n$ & $\%$ & $n$ & $\%$ & $n$ & $\%$ & & & \\
\hline Rasa & 6 & 8,31 & 0 & 0,25 & 9 & 13,23 & 44 & 65,77 & 8 & 12,44 & 183 & 2,7 & 45,9 \\
\hline Tekstur & 6 & 8,31 & 0 & 0,55 & 11 & 16,87 & 44 & 65,52 & 6 & 8,76 & 178 & 2,7 & 44,5 \\
\hline Warna & 6 & 8,31 & 0 & 0,10 & 8 & 11,24 & 48 & 72,34 & 5 & 8,01 & 182 & 2,7 & 45,5 \\
\hline Aroma & 6 & 8,31 & 0 & 0,35 & 7 & 11,14 & 45 & 67,66 & 8.4 & 12,54 & 185 & 2,8 & 46,2 \\
\hline
\end{tabular}

Santri sebagian besar menilai pada tingkatan
sangat suka pada setiap karakteristik yaitu rasa $(12,44 \%)$, tekstur $(8,76 \%)$, warna $(8,01 \%)$, dan aroma $(12,54 \%)$. Nilai rata-rata skor yang jika dibulatkan bernilai 3 yang berarti termasuk kategori suka. Skor tertinggi yang didapatkan pada karakteristik makanan yang ada disana yaitu aroma makanan yang sebesar 185. Hal ini dikarenakan sebagian santri berpendapat bahwa yang mampu meningkatkan rasa lapar ketika waktu makan akan tiba adalah dengan mencium aroma makanan yang ketika proses pengolahan sudah tercium sedap oleh santri.

Mutu makanan pada penelitian ini dinilai berdasarkan tingkat kesukaan santri terhadap menu dalam sehari yang telah dibuat oleh penyelenggara makanan di pondok pesantren Al Izzah IIBS Batu. Hasil skor rata-rata tingkat kesukaan keseluruhan menu yang diuji terhadap karakteristik makanan dapat dijadikan sebagai tingkat capaian responden (TCR) sehingga penilaian mutu makanan suatu penyelenggaraan makanan dapat ditentukan kategorinya. Berdasarkan hasil yang didapat, TCR pada seluruh karakteristik makanan di Al Izzah mendapatkan nilai 45,52 yang berarti mutu makanan termasuk dalam kategori cukup baik.

Berdasarkan hasil penelitian mengenai tingkat kesukaan menu terhadap hidangan makanan pokok yang berupa nasi putih, mayoritas responden menyukai warna nasi saat disajikan yang berwarna putih bersih. Hal ini karena nasi yang dimasak berasal dari beras selepan yang dibersihkan terlebih dahulu dan dimasak setiap jam makan sekali, sehingga tidak dilakukan pemanasan secara berulang yang dapat mempengaruhi perubahan warna nasi menjadi kekuningan. Namun karakteristik nasi yang paling banyak dinilai tidak suka oleh santri ialah teksturnya. Hal ini selaras pula dengan penelitian Anggiruling (2016) sebagian santri menilai jika nasi yang disediakan pondok pesantren masih sedikit keras. Hal ini dikarenakan sebagian subjek menilai nasi akan terasa lebih enak jika di olah menjadi nasi goreng karena ada tambahan rasa kecap dan telur ${ }^{11}$.

Tingkat kesukaan santri terhadap hidangan lauk hewani yang berupa telur dan daging ayam dengan skor tertinggi secara keseluruhan berasal dari rasa makanan. Hal ini dikarenakan menurut sebagian besar santri hidangan lauk hewani di pesantren telah mempunyai cita rasa yang enak. Hasil ini sejalan dengan penelitian Zakiatul (2016) yang menilai banyak responden menyukai rasa dari lauk hewani karena meskipun menu makanan sederhana namun jika penambahan bumbu tepat pada saat proses pengolahan akan menghasilkan rasa yang sedap ${ }^{12}$. terhadap lauk nabati yang berupa tahu dan tempe dengan skor tertinggi terdapat pada aroma lauk nabati yang memang harum. Hidangan lauk nabati dengan skor terendah adalah teksturnya. Hal ini tidak selaras dengan penelitian Paling (2019) yang mana penilaian tertinggi terdapat pada tekstur yang berupa kelembutan serat protein nabati yang diamati dengan indera peraba dan dikelompokkan menjadi 3 kategori yaitu tidak empuk, agak empuk dan empuk.

Berdasarkan hasil penelitian tingkat kesukaan santri terhadap hidangan sayuran yang berupa sayur asam bening dan oseng kacang panjang dengan skor tertinggi adalah pada rasanya. Proses pemanasan yang dilakukan dalam pengolahan hidangan sayuran dapat mengakibatkan unsur zat sayuran menyusut karena suhu pada luar permukaan sayur meningkat kemungkinan memengaruhi rasa pada sayuran ${ }^{13}$. Lalu yang mempunyai skor terendah ada pada tekstur sayur. Hal ini karena sayur terlalu lama dipanaskan meskipun hidangan sayuran biasanya diolah sejam sebelum jam makan dimulai.

Tingkat kesukaan santri terhadap hidangan buah melon yang hanya disajikan pada saat makan siang saja dengan skor tertnggi yaitu tekstur buah melon yang tidak terlalu keras sehingga mudah untuk dikonsumsi. Namun sebanyak $13,4 \%$ santri menilai tidak suka terhadap rasa buah melon yang sedikit hambar sehingga kurang manis. Buah yang akan dikonsumsi dalam keadaan matang, bila dipanen pada keadaan masih muda akan mempunyai warna kulit yang tidak merata ketika matang ${ }^{14}$, rasa yang kurang enak, aroma yang kurang bila dibandingkan dengan buah yang matang normal, yaitu buah yang sama tetapi dipanen dalam keadaan tua penuh.

Tabel 3. Distribusi Daya Terima Makanan Santri dalam Sehari

\begin{tabular}{lcc}
\hline \multirow{2}{*}{ Daya Terima } & \multicolumn{2}{c}{ Jumlah $(\mathrm{n}=67)$} \\
\cline { 2 - 3 } & $\mathrm{n}$ & $\%$ \\
\hline $\begin{array}{l}\text { Daya Terima Baik } \\
\text { (Sisa makanan <20\%) }\end{array}$ & 66 & 98,5 \\
\hline $\begin{array}{l}\text { Daya Terima Buruk } \\
\text { (Sisa makanan }>20 \%)\end{array}$ & 1 & 1,5 \\
\hline
\end{tabular}

Daya Terima Konsumsi pada Penyelenggaraan Makanan

Distribusi santri menurut daya terima santri terhadap makanan yang disajikan pada penyelengara makanan pondok pesantren dalam sehari dihitung melalui penimbangan sisa makanan yang berasal dari 
penyelenggara makanan di pondok pesantren Al Izzah IIBS Batu selama sehari yang dapat dilihat pada tabel 3 . Apabila dilihat secara mayoritas, nilai daya terima makanan santri SMA Al Izzah IIBS sudah baik karena hanya sejumlah $1,5 \%$ responden yang makanannya bersisa lebih dari $20 \%$ dari porsi makanan.

Penilaian kepuasan konsumen dalam suatu jasa boga atau penyelenggaraan makanan adalah dengan menggunakan aspek daya terima karena merupakan produk akhir dari makanan. Daya terima biasanya diukur dengan perhitungan sisa makanan. Sisa makanan harus diperhatikan karena menentukan apakah makanan disukai atau tidak. Semakin sedikit sisa makanan, mengindikasikan bahwa semakin disukai produk yang disajikan ${ }^{15}$.

Penimbangan sisa makanan yang tertinggal di piring adalah metode yang paling akurat, tetapi metode ini mempunyai kelemahan yaitu memerlukan waktu yang banyak, peralatan khusus dan staf yang terlatih, sehingga metode ini tidak mungkin dilakukan untuk penelitian besar. Namun karena pada penelitian ini hanya menggunakan santri sebagai responden yang berjumlah 67 orang sehingga ada kemungkinan untuk melakukan metode penimbangan sisa makanan yang dibantu oleh tiga pembantu peneliti. Cahyawari (2013) juga menjelaskan bahwa jumlah presentase konsumen yang menyisahkan makanan $<20 \%$ menunjukkan daya terima konsumen adalah baik.

Berdasarkan hasil penelitian menurut jenis hidangan, menunjukkan bahwa makanan pokok meskipun hanya berupa nasi putih tetapi yang memiliki sisa makanan paling sedikit adalah di waktu pagi hari yaitu sebesar $94 \%$ santri yang daya terimanya baik. Lauk hewani hanya disediakan pada waktu pagi dan siang hari saja dan yang memiliki daya terima baik yaitu pada saat makan pagi dengan presentase $61 \%$. Lauk nabati memiliki nilai daya terima baik yang hampir sama di tiap waktu makannya yaitu sekitar $88,1 \%$ hingga $89,6 \%$. Hidangan sayur yang disajikan pada saat pengambilan data, disediakan pada waktu makan siang dan makan malam dengan menu yang berbeda tetapi sebagian responden mempunyai daya terima baik pada saat makan malam yaitu sebesar $94 \%$. Sedangkan buah sudah pasti memiliki daya terima yang baik hanya pada makan siang saja yaitu dengan presentase sebesar $97 \%$. Hal ini karena buah memang hanya disajikan pada saat jam makan siang. Namun hasil daya terima ini hanya merepresantasikan menu dalam sehari saja yaitu pada saat peneliti menimbang sisa makanan santri.

Sedangkan hasil penelitian sisa makanan semua hidangan dalam sehari dapat dilihat bahwa daya terima yang masih buruk atau karena sisa makanan yang banyak ialah nasi dan lauk hewani, yaitu sebesar $13,4 \%$. Hasil penelitian ini selaras dengan penelitian yang dilakukan oleh Cahyawari (2013) yang menunjukkan bahwa rata-rata sisa makanan pasien bersisa banyak (>20\%) pada jenis makanan pokok yaitu sebesar $53,3 \%$. Sedangkan daya terima makanan paling baik adalah buah, yaitu sebesar 97,0\%. Beberapa alasan yang diberikan oleh responden yang makanannya bersisa adalah karena sedang tidak mood untuk makan, merasa kenyang karena telah memakan banyak snack pada jam istirahat sebelumnya, serta sedang merasa tidak enak badan sehingga menurunkan selera makan.

Tabel 4. Rekapitulasi Distribusi Hubungan Karakteristik Santri dan Mutu Makanan dengan Daya Terima

\begin{tabular}{|c|c|c|c|c|c|c|c|c|c|}
\hline \multirow{2}{*}{ No } & \multirow{2}{*}{ Variabel } & \multicolumn{2}{|c|}{ Buruk } & \multicolumn{2}{|c|}{ Baik } & \multicolumn{2}{|c|}{ Total } & \multirow{2}{*}{$p$-value } & \multirow{2}{*}{ OR } \\
\hline & & $\mathrm{n}$ & $\%$ & $\mathrm{n}$ & $\%$ & $\mathrm{n}$ & $\%$ & & \\
\hline \multirow[t]{3}{*}{1} & Usia & & & & & & & & \\
\hline & $15-16$ & 0 & 0 & 41 & 100,0 & 41 & 61,2 & \multirow{2}{*}{0,38} & \multirow{2}{*}{1,040} \\
\hline & $17-18$ & 1 & 3,8 & 25 & 96,2 & 26 & 38,8 & & \\
\hline \multirow[t]{3}{*}{2} & Tingkat Pendidikan & & & & & & & & \\
\hline & 10 & 0 & 0 & 36 & 100,0 & 36 & 53,7 & \multirow{2}{*}{0,46} & \multirow{2}{*}{1,033} \\
\hline & 11 & 1 & 3,2 & 30 & 96,8 & 31 & 46,3 & & \\
\hline \multirow[t]{3}{*}{3} & Asal Daerah & & & & & & & & \\
\hline & Jawa & 0 & 0 & 47 & 100,0 & 47 & 70,1 & \multirow{2}{*}{0,29} & \multirow{2}{*}{1,053} \\
\hline & Luar Jawa & 1 & 5,0 & 19 & 95,0 & 20 & 29,9 & & \\
\hline \multicolumn{10}{|c|}{$4 \quad$ Mutu Makanan } \\
\hline & Kurang & 0 & 0 & 19 & 100,0 & 19 & 28,4 & \multirow[b]{2}{*}{1,00} & \multirow[b]{2}{*}{0,985} \\
\hline & Cukup & 1 & 2,1 & 47 & 97,9 & 48 & 71,6 & & \\
\hline \multicolumn{5}{|c|}{$\begin{array}{l}\text { Hubungan Karakteristik Santri dengan Daya Terima } \\
\text { Konsumsi } \\
\text { Hubungan Usia dengan Daya Terima Konsumsi. } \\
\text { Berdasarkan hasil uji statistik hubungan antara usia } \\
\text { dengan daya terima konsumsi didapatkan hasil p-value } \\
0,38(p<0,10) \text {, hal ini menunjukkan bahwa tidak terdapat } \\
\text { hubungan yang bermakna antara usia dengan daya } \\
\text { terima konsumsi. Hasil penelitian ini sesuai dengan } \\
\text { pendapat ahli yang dapat disimpulkan bahwa kepuasan } \\
\text { bersifat subjektif merupakan hasil reaksi afeksi } \\
\text { (penilaian perasaan), meskipun objek yang dinilai adalah }\end{array}$} & & \multicolumn{4}{|c|}{$\begin{array}{l}\text { sama }^{16} \text {. Reaksi afeksi seseorang yang menghasilkan } \\
\text { penilaian sama atau berbeda sangat ditentukan oleh } \\
\text { latar belakang atau karakteristik individu, seperti suku } \\
\text { bangsa dengan nilai budaya yang dianut, pendidikan, } \\
\text { usia, jenis kelamin, pekerjaan, status perkawinan atau } \\
\text { pendapatan }{ }^{17} \text {. Hasil penelitian ini tidak selaras dengan } \\
\text { penelitian Noviati (2004) yang menunjukkan ada } \\
\text { hubungan karakteristik pasien meliputi umur, } \\
\text { pendidikan, dan penghasilan dengan daya terima } \\
\text { konsumsi pasien di Instalasi Gawat Darurat RSUD Pasar } \\
\text { Rebo }{ }^{18} \text {. Penelitian ini menunjukkan bahwa semakin tua }\end{array}$} \\
\hline
\end{tabular}


usia seseorang maka tidak akan menuntut hal yang lebih idealis dibanding yang berusia lebih muda.

Hubungan Tingkat Pendidikan dengan Daya Terima Konsumsi. Berdasarkan hasil uji statistik hubungan antara tingkat pendidikan dengan daya terima konsumsi didapatkan hasil $p$-value $0,46(p>0,10)$, hal ini menunjukkan bahwa tidak ada hubungan yang bermakna antara tingkat pendidikan dengan tingkat kepuasan konsumsi. Hasil ini tidak selaras dengan teori, semakin tinggi tingkat pendidikan seseorang maka akan semakin mengerti terhadap pentingnya kualitas produk atau pelayanan yang akan dikonsumsi atau diterima sehingga dapat meningkatkan rasa puas setelahnya ${ }^{19}$. Hasil penelitian ini juga tidak sejalan dengan Noviati (2004) yang menunjukkan ada hubungan karakteristik pasien meliputi usia, pendidikan, dan penghasilan dengan daya terima konsumsi pasien di Instalasi Gawat Darurat RSUD Pasar Rebo ${ }^{18}$. Namun hal ini bisa juga terjadi karena metode pengambilan sampel yang secara Proportionate Stratified Random Sampling sehingga jumlah santri kelas 10 lebih banyak dibanding jumlah santri kelas 11 .

Hubungan Asal Daerah dengan Daya Terima Konsumsi. Berdasarkan hasil uji statistik hubungan asal daerah dengan tingkat kepuasan konsumsi didapatkan nilai $p$-value $0,29(p>0,10)$, hal ini menunjukkan bahwa tidak terdapat hubungan yang bermakna antara asal daerah dengan daya terima konsumsi. Hal ini berkebalikan dengan Richard (2004) yang menyatakan bahwa konsumen memiliki sifat yang individual dan setiap orang akan memandang sesuatu secara berbeda dari orang lain meskipun dalam situasi yang sama. Perbedaan perspektif tersebut antara lain disebabkan oleh perbedaan latar belakang, jenis kelamin, usia, dan pendidikan. Meskipun jika dilihat dari hasil penelitian, santri yang memiliki daya terima baik lebih banyak yang berasal dari Jawa dibanding dari Luar Jawa. Hal tersebut menunjukkan bahwa terdapat kecenderungan santri yang berasal dari daerah Jawa mempunyai daya terima konsumsi dengan kategori baik, meskipun tidak cukup kuat untuk menunjukkan ada hubungan yang berarti. Sebab orang yang berasal dari Jawa umumnya identik dengan cita rasa manis pada makanan ${ }^{20}$, tetapi selain itu juga bisa mempertimbangkan dimana lokasi penelitian tersebut diadakan karena mempengaruhi sebaran asal daerah responden penelitian masing-masing.

\section{Hubungan Mutu Makanan dengan Daya Terima Konsumsi}

Pada hasil uji statistik didapatkan p-value 1,00 $(p>0,10)$ yang berarti tidak ada hubungan yang signifikan antara mutu makanan dengan daya terima konsumsi. Hal ini berarti mutu makanan yang disediakan pada penyelenggara makanan di Al Izzah IIBS Batu tidak memberi pengaruh pada daya terima konsumsi santri. Hal tersebut karena pengambilan data hanya dilakukan dalam sehari maka hasil uji statistik kurang bermakna. Namun pada menu makanan yang diuji oleh peneliti, menu tahu dan tempe goreng yang masih rendah tingkat kesukaannya sehingga dapat mempengaruhi daya terima.
Selain itu juga dapat disebabkan karena nafsu makan pada remaja yang sering berubah dan status kesehatan santri seperti penelitian sebelumnya yang menunjukkan bahwa ada hubungan bermakna antara nafsu makan, porsi, suhu, sikap petugas dengan kepuasan penyediaan makanan pagi, siang, dan sore ${ }^{21}$. Namun, berdasarkan hasil penelitian menunjukkan bahwa mutu makanan pada menu yang diuji memiliki kategori cukup dan daya terima konsumsi yang berkategori baik lebih besar dibandingkan dengan mutu makanan yang berkategori cukup dan buruk. Hal tersebut menunjukkan bahwa terdapat kecenderungan mutu makanan yang masuk kategori cukup memiliki daya terima konsumsi baik, meskipun pada uji statistik tidak cukup kuat untuk menunjukkan terdapat hubungan antara mutu makanan dengan daya terima konsumsi karena pengambilan data hanya dilakukan pada satu hari saja bukan dalam satu masa siklus menu.

Hasil penelitian ini tidak sejalan dengan penelitian sebelumnya, bahwa tingkat kesukaan responden terhadap makanan sangat bergantung signifikan terhadap daya terima konsumennya ${ }^{22}$. Pada penelitian tersebut menunjukkan bahwa semakin suka dengan menu makanan yang disediakan pondok maka daya terima terhadap menu yang disediakan juga semakin tinggi dan sebaliknya. Hal ini sesuai dengan pernyataan Nurdiani (2011) bahwa tingkat kesukaan akan mempengaruhi daya terima siswa terhadap menu yang disajikan. Semakin tinggi tingkat kesukaan siswa maka makanan yang dihabiskan akan semakin tinggi. Penelitian ini juga tidak sejalan dengan penelitian sebelumnya, bahwa kualitas atau mutu produk memiliki pengaruh terhadap loyalitas pelanggan yang lebih kecil dibandingkan pengaruh kualitas produk terhadap kepuasan pelanggan ${ }^{23}$. Artinya, mutu makanan memengaruhi puas atau tidaknya konsumen yang akan berdampak kepada daya terima konsumsinya.

Meskipun hasil pada penelitian ini tidak ada hubungan, akan tetapi ada kecenderungan mutu makanan yang baik memiliki daya terima konsumsi yang baik. Hal tersebut sesuai dengan Istianto (2011) bahwa terdapat lima dimensi yang memengaruhi perasaan kepuasan konsumen, yaitu: mutu makanan, ketepatan waktu penyajian, realibilitas pelayanan, temperature makanan serta sikap petugas penyaji makanan ${ }^{24}$. Kepuasan terhadap makanan yang disajikan dikatakan bermutu baik jika makanan tersebut mempunyai cita rasa yang tinggi, penampilan, aroma, dan penyajian yang menarik.

\section{KESIMPULAN}

Penyelenggaraan makanan pada SMA Al Izzah IIBS Batu yang sebagian besar konsumennya termasuk dalam remaja pertengahan dan berasal dari Jawa, secara keseluruhan telah menerapkan proses manajemen yang telah berlaku namun masih terdapat kekurangan pada proses kegiatan penyimpanan bahan makanan pada beras yang tidak menggunakan alas, serta belum menerapkan kegiatan pelaporan dan pencatatan di setiap sub kegiatan manajemen. Mutu makanan pada penyelenggaraan makanan di SMA Al Izzah IIBS Batu sudah termasuk dalam kategori cukup baik meskipun 
jumlah hidangan dalam sehari masih belum sesuai ketentuan. Daya terima santri SMA Al Izzah IIBS Batu sebagian besar sudah tergolong baik Tidak ada hubungan antara karakteristik santri (usia, tingkat pendidikan, dan asal daerah) dengan daya terima konsumsi. Tidak ada hubungan antara mutu makanan dengan daya terima konsumsi pada penyelenggaraan makanan di Al Izzah IIBS Batu.

\section{ACKNOWLEDGEMENT}

Ucapan terima kasih diberikan kepada kepala SMA Al Izzah IIBS Batu karena telah mengijinkan peneliti untuk melakukan penelitian dan pengambilan data di sekolah tersebut. Selain itu, peneliti juga mengucapkan terima kasih kepada penanggung jawab penyelenggaraan makanan dan seluruh patugas dapur yang telah membantu dalam mengumpulkan data serta santri di pondok pesantren tersebut yang telah bersedia menjadi responden.

\section{REFERENSI}

1. Syafe'i, I. PONDOK PESANTREN: LEMBAGA PENDIDIKAN PEMBENTUKAN KARAKTER. J. Pendidik. Islam 8, 61-82 (2017).

2. Adriani, M., and Wirjatmadi, B. Pengantar Gizi Masyarakat. (Kencana, 2013).

3. Taqhi, A. The Description of Food Procurement Systemat the Hubulo Islamic Boarding School, Gorontalo. J. MKMI 241-247 (2014).

4. Semedi, P. \& Kartasurya, M. I. Hubungan kepuasan pelayanan makanan rumah sakit dan asupan makanan dengan perubahan status gizi pasien ( Studi di RSUD Sunan Kalijaga Kabupaten Demak ). 2, (2013).

5. Sugiyono. Statistika UntuMoehyi, M. and. (1992). Pengetahuan Bahan Makanan. Jakarta: Balai Pustaka.k Penelitian. (Alfabeta, 2011).

6. Moehyi, M. and. Pengetahuan Bahan Makanan. (Balai Pustaka, 1992).

7. Bakri, B., Intiyati, A., and W. Sistem Penyelenggaraan Makanan Institusi. (PPSDM Kesehatan, 2018).

8. Soetjiningsih. Tumbuh Kembang Anak. (Fakultas Kedokteran UI, 2007).

9. Azwar, S. Sikap Manusia: Teori dan Pengukurannya. (Pustaka Pelajar, 2010).

10. Wulansari, A., Setiawan, B., and Sinaga, T. Penyelenggaraan Makanan dan Tingkat Kepuasan Konsumen. J. Gizi dan Pangan 8(2), 151-158 (2013).

11. Anggiruling, D. O. EVALUASI SISTEM PENYELENGGARAAN MAKANAN DI PONDOK PESANTREN AL-MUSYARROFAH. (2016).

12. Ismawati, R. STUDI TENTANG TINGKAT KESUKAAN RESPONDEN TERHADAP PENGANEKARAGAMAN LAUK PAUK DARI DAUN KELOR ( Moringa oleivera ). e-Journal Boga $\mathbf{5}$, 17-22 (2016).
13. Fitriyani. Eksperimen Pembuatan Roti Tawar dengan Penggunaan Sari Bayam (Amaranthus sp.). Food Scien Culin. Educ. J. 2, 16-23 (2013).

14. Ahmad, A., Kashif-ur-Rahman, Saif, I., and Safwan, N. An Empirical Investigation of Islamic Banking in Pakistan based on Perception of Service Quality Corporate Social Responsibility in Pakistan: A Case of Services Sector View project. African J. Bus. Manag. 4(6), 1185-1193 (2010).

15. Cahyawari, M. M. HUBUNGAN ANTARA KUALITAS PELAYANAN MAKANAN DAN TINGKAT KEPUASAN DENGAN SISA MAKANAN PASIEN DIABETES MELLITUS TIPE II RAWAT INAPDI RS PKU MUHAMMADIYAH SURAKARTA. (Universitas Muhammadiyah Surakarta, 2013).

16. Azwar, A. Menuju Pelayanan Kesahatan yang Lebih Bermutu. (Yayasan Penerbitan Ikatan Dokter Indonesia, 1996).

17. Utama, A. Analisis Pengaruh Persepsi Kualitas Pelayanan Terhadap Kepuasan Pelanggan Rumah Sakit Umum Cakra Husada Klaten. OPSI 1, 96-110 (2003).

18. Noviati, T. Analisis Hubungan Faktor-Faktor Karakteristik Pasien dengan Kepuasan Melalui Pengukuran Harapan dan Persepsi Pasien di Instalasi Gawat Darurat Rumah Sakit Umum Daerah Pasar Rebo. (Universitas Indonesia, 2004).

19. Sumarwan, U. Perilaku Konsumen dan Penerapannya dalam Pemasaran. (Ghalia Indonesia, 2011).

20. Hendrayani, I. N. GULAKU DI KOTA BOGOR ( Studi Kasus di Giant Botani Square dan Ramayana BTM ) Oleh: PROGRAM STUDI MANAJEMEN AGRIBISNIS. (Institut Pertanian Bogor, 2008).

21. Sari, E. W. L. FAKTOR - FAKTOR YANG BERHUBUNGAN DENGAN KEJADIAN PREEKLAMPSIA DI RSUD DR. MOEWARDI SURAKARTA. (Universitas Muhammadiyah Surakarta, 2009).

22. Lubis, M. Z. TINGKAT KESUKAAN DAN DAYA TERIMA MAKANAN SERTA HUBUNGANNYA DENGAN KECUKUPAN ENERGI DAN ZAT GIZI PADA SANTRI PUTRI MTS DARUL MUTTAQIEN BOGOR. (Institut Pertanian Bogor, 2015).

23. Fiani, M., Edwin, S., Pemasaran, J. M., Petra, U. K. \& Siwalankerto, J. ANALISA PENGARUH FOOD QUALITY DAN BRAND IMAGE TERHADAP KEPUTUSAN PEMBELIAN ROTI KECIK TOKO ROTI GANEP' S DI KOTA SOLO. J. Manaj. Pemasar. 1, 1-6 (2012).

24. Istianto, J. H. Analisis Pengaruh Kualitas Layanan Terhadap Kepuasan Pelanggan Rumah Makan Ketty Resto. J. Ekon. dan Inf. Akutansi 1(3), (2011). 